\title{
Het klinisch beloop bij gemetastaseerd prostaatcarcinoom
}

\author{
Ronald W. ter Haar' · Liselotte M. S. Boevé' · Jasper J. Hillenius' • George van Andel'
}

Published online: 9 September 2019

(c) The Author(s) 2019

\section{Samenvatting}

Van de patiënten met een prostaatcarcinoom heeft $16 \%$ bij het stellen van de diagnose al botmetastasen. Nog eens $30 \%$ van de patiënten ontwikkelt later botmetastasen. Dit artikel biedt een overzicht van de literatuur over het klinisch beloop van het gemetastaseerde prostaatcarcinoom. Ook worden de resultaten gepresenteerd van twee Nederlandse studies naar het klinisch beloop bij prostaatcarcinoom. De meest frequent voorkomende relevante klinische problemen zijn: fractuur (10-15\%), (in)complete dwarslaesie (10-15\%), blaasontledigingsstoornissen waarvoor CIC, CAD, SP of een TURP (25\%), symptomatische hydronefrose door obstructie van de distale ureter waarvoor een nefrodrain of JJ noodzakelijk is $(5 \%)$, anemie waarvoor bloedtransfusie(s) nodig is (zijn) (35\%), ziekenhuisopname vanwege aan het prostaatcarcinoom gerelateerde problemen (75\%) en palliatieve bestraling(en) in verband met pijnlijke botmetastasen (55\%). Tot slot wordt op hoofdlijnen een overzicht gegeven van de meest gangbare behandelingen van voornoemde problemen.

Trefwoorden prostaatkanker $\cdot$ metastasen $\cdot$ klinisch beloop $\cdot$ behandeling

\section{Clinical course of metastatic prostate cancer}

\begin{abstract}
$16 \%$ of the patients with prostate cancer have bone metastases at the time of primary diagnosis. Another $30 \%$ of patients develop bone metastases during the course of the illness. This article first of all provides an overview of what is known from literature on the clinical course of metastatic prostate cancer. Subsequently, the results are presented of two Dutch studies giving insights in the clinical course of these patients. The most frequently occurring, relevant clinical problems are: fracture (10-15\%), spinal cord compression (10-15\%), bladder outlet obstruction for which CIC, CAD, SP or TURP (25\%), symptomatic hydronephrosis due to obstruction of the distal ureter for which a nephrostomy tube or JJ is required (5\%), blood transfusion because of anaemia (35\%), hospitalization for prostate cancer related problems (75\%) and radiation therapy for (painful) bone metastasis (55\%). Finally, an outline is given of the most common treatments for the aforementioned problems.
\end{abstract}

Keywords prostate cancer $\cdot$ metastasis $\cdot$ clinical course $\cdot$ therapy

\section{Introductie}

In 2018 is in Nederland bij 12.600 mannen de diagnose prostaatkanker gesteld (1,5 per 1.000 mannen). Van deze patiënten heeft $16 \%$ bij het stellen van de diagnose al botmetastasen, daarnaast ontwikkelt ongeveer $30 \%$ van de patiënten die in opzet curatief zijn behandeld of bij wie een

\footnotetext{
dr. George van Andel

g.vanandel@olvg.nl

1 afdeling Urologie, OLVG, Amsterdam, Nederland
}

waakzaam afwachtend beleid is gevoerd op termijn toch (bot)metastasen [1, 2]. Hoewel de problemen die zich bij patiënten met een gemetastaseerd prostaatcarcinoom voordoen tijdens het beloop bekend zijn uit de dagelijks praktijk, zijn hierover maar uiterst beperkt data gepubliceerd. Dit geldt evenzeer voor de verscheidenheid aan toegepaste palliatieve behandelingen.

In dit artikel wordt een overzicht gegeven van de actuele literatuur met betrekking tot het klinisch beloop van het gemetastaseerd prostaatcarcinoom. Verder worden de resultaten gepresenteerd van twee Nederlandse prospectieve studies naar het klinisch beloop bij deze patiëntengroep 
(de Registratiestudie 2004 en de HORRAD-studie 2018) en worden op hoofdlijnen de palliatieve therapeutische mogelijkheden besproken.

\section{Literatuuroverzicht}

Er is een uitgebreide PubMed-search verricht op onder andere de volgende trefwoorden: prostaat, carcinoom, metastasen, castratieresistent, klachten, anemie, vermoeidheid, LUTS, hematurie, pijn, fracturen en dwarslaesie. Daarnaast zijn de reguliere handboeken geraadpleegd [3-6]. Het aantal artikelen dat specifiek de aan de ziekte gerelateerde problemen die zich voordoen bij patiënten met een gemetastaseerd prostaatcarcinoom beschrijft, is uiterst beperkt. Een internationale survey onder 927 patiënten met gemetastaseerd prostaatcarcinoom laat zien dat vermoeidheid (73\%), mictieklachten (63\%), seksuele disfunctie (62\%) en botpijn (52\%) de meest gerapporteerde klachten zijn. In wisselende mate worden gewichtsverlies, cognitieve achteruitgang, misselijkheid en verminderde voedselintake, en angst- en slaapstoornissen gerapporteerd [7].

Op basis van de gevonden literatuur, maar ook op basis van de handboeken, resultaten van de twee Nederlandse studies die verderop besproken worden en klinische ervaring, zijn de meest relevante en frequentst voorkomende problemen gesignaleerd, namelijk: anemie, dwarslaesie (incompleet/compleet), fractuur, hematurie, lymfoedeem, mictieklachten, pijn, symptomatische hydronefrose (postrenaal) en vermoeidheid.

De klachten ten gevolge van de hormonale behandeling zijn onder andere: libidoverlies, erectiestoornissen, een verminderd gevoel van mannelijkheid, opvliegers en afname van spiermassa. Deze klachten zijn inherent aan de behandeling en er bestaat, behoudens enkele praktische adviezen hoe ermee om te gaan, geen wezenlijke therapie voor. De meeste patiënten accepteren dit feit en in het beloop van hun gemetastaseerde ziekte hebben deze klachten geen grote invloed meer op de algehele kwaliteit van leven, noch op het mentale welzijn van de patiënt. Daarom zullen we deze klachten hier niet verder bespreken.

De gevolgen van de ziekteprogressie en de behandeling van voortschrijdende ziekte bij patiënten met een gemetastaseerd prostaatcarcinoom zijn divers en hebben een grote invloed op zowel de lichamelijke, mentale als de algehele kwaliteit van leven. Gemetastaseerd prostaatcarcinoom leidt dus tot een aanzienlijke morbiditeit en medische consumptie en heeft daarmee een grote sociaal-economische impact $[8,9]$.

Hieronder volgt een overzicht van de relevante en meest frequent voorkomende problemen die in de literatuur beschreven staan.

\section{Anemie}

Hoewel anemie frequent voorkomt bij patiënten met een gemetastaseerd prostaatcarcinoom, zijn concrete data met betrekking tot de incidentie maar beperkt beschikbaar. Op het moment van het stellen van de diagnose ossaal gemetastaseerd prostaatcarcinoom, heeft ongeveer $30 \%$ van de patiënten een anemie $[10,11]$. De etiologie van anemie bij gemetastaseerd prostaatcarcinoom is complex en berust op meerdere factoren. Anemie die direct samenhangt met (de progressie) van de prostaatkanker zelf of met de behandeling, kan onderverdeeld worden in verminderde bloedaanmaak, verhoogde bloedafbraak en bloedverlies. De bloedaanmaak kan vertraagd worden door onder andere beenmerginvasie, myelosuppressieve chemotherapie, radiotherapie, nutritionele deficiënties (ijzer, vitamine $\mathrm{B}_{12}$, foliumzuur) of inflammatie met als gevolg een functioneel ijzertekort [12]. Kankercellen produceren tevens inflammatoire cytokinen die de productie van endogeen erytropoëtine (EPO) remt. Omdat testosteron de aanmaak van EPO in de nier stimuleert, is ook castratie een oorzaak van anemie, met name bij totale androgeenblokkade (LHRH-agonist plus een anti-androgeen). Toch leidt het starten van een LHRHagonist slechts in $<5 \%$ van de gevallen tot een anemie [11]. Toegenomen bloedafbraak door hemolyse of hemofagocytose is zeldzaam bij solide tumoren. Bloedverlies kan optreden door lokale doorgroei van het prostaatcarcinoom of als gevolg van een (radiatie)cystitis dan wel prostatitis. Indien er geen aanwijzingen zijn voor een aan de prostaatkanker gerelateerde anemie dient verder onderzoek verricht te worden naar andere oorzaken, waaronder bloedverlies uit de tractus digestivus.

\section{Dwarslaesie (incompleet/compleet)}

Wervelmetastasen komen voor bij $25-75 \%$ van de oncologische patiënten met gemetastaseerde ziekte. Bij 1-5\% van de patiënten leidt de metastase tot epidurale dan wel spinale myelum- of caudacompressie, hetgeen zich klinisch kan uiten in pijn, neurologische uitval (incomplete/complete dwarslaesie) en een caudasyndroom (urineretentie, overloopincontinentie en obstipatie) [13]. Van de wervelmetastasen betreft het in meer dan $50 \%$ van de gevallen uitzaaiingen van mama-, long- of prostaatcarcinoom [14]. In de literatuur zijn geen gegevens beschikbaar over de incidentie van wervelmetastasen bij patiënten met prostaatkanker en ook niet of en in hoeverre deze tot klinische symptomen leiden.

\section{Fractuur}

Fracturen treden veelal op als gevolg van een trauma. Het percentage spontane fracturen is klein. De kans op een 
fractuur is groter in geval van verminderde botdichtheid ten gevolge osteoporose of een metastase. In meerdere studies is aangetoond dat de kans op osteoporose en fracturen groter is bij hormonale behandeling van prostaatkanker in vergelijking met niet-hormonale behandeling en eveneens in vergelijking met een populatie zonder prostaatkanker [15], maar ook een populatie patiënten met prostaatkanker die niet-hormonaal behandeld wordt heeft een iets grotere (significante) kans op fracturen dan een populatie zonder prostaatkanker [16]. In grote populaties is de overall kans op osteoporotische fracturen circa $8 \%$. In de literatuur hebben we geen gegevens gevonden over het percentage fracturen ten gevolge van een metastase bij patiënten met een gemetastaseerd prostaatcarcinoom.

\section{Hematurie}

Hematurie is een frequent voorkomende klacht bij patiënten met gemetastaseerd prostaatcarcinoom. In de literatuur hebben we geen exacte gegevens gevonden over de frequentie van hematurie. Hematurie kan optreden als gevolg van lokale progressie van de tumor met doorgroei in de blaas of de urethra prostatica. Hematurie kan ook het gevolg zijn van eerdere lokale radiotherapie (radiatiecystitis dan wel prostatitis). Hoewel er zelden sprake is van acuut levensbedreigend bloedverlies, kan hematurie wel leiden tot anemie en stolselretentie, met als gevolg frequente en langdurige ziekenhuisopnames, wat door de patiënt en zijn familie als zeer belastend kan worden ervaren. Indien de hematurie niet verklaard kan worden door een van de voornoemde oorzaken, komen andere oorzaken in beeld voor hematurie, waaronder urolithiasis, infecties en een tweede tumor dan wel metastasen in de tractus urogenitalis. Tot slot gebruikt een substantieel deel van de patiënten bloedverdunnende medicatie, hetgeen vanzelfsprekend een rol speelt bij het optreden van de hematurie.

\section{Lymfoedeem}

Lymfoedeem is een (zichtbare) zwelling van weefsel door ophoping van eiwitrijk vocht in het interstitium, ten gevolge van een aanleg- of functiestoornis van lymfestructuren of een afvloedbelemmering van de lymfevaten [17]. Zonder behandeling is lymfoedeem een progressieve aandoening, die kan leiden tot pijn, functievermindering en bewegingsbeperking. Als gevolg hiervan bestaat er een vergrote kans op het optreden van diepe veneuze trombose, met name in de benen.

De belangrijkste oorzaken van lymfoedeem bij patiënten met prostaatkanker zijn:

- lymfeklierdissectie in het bekken;
- bestraling van het bekken of de lies (dit geeft fibrosering van het lymfesysteem);

- lymfangitis carcinomatosis c.q. ingroei en/of compressie van lymfevaten of lymfeklieren door een (recidief)tumor of door metastasen.

In sommige gevallen ontstaat of verergert lymfoedeem als gevolg van uitlokkende factoren, zoals:

- infecties, trauma of overbelasting van het been;

- veneuze afvloedbelemmering door veneuze insufficiëntie, trombose of veneuze compressie door de tumor.

Daarnaast is perifeer (lymf)oedeem beschreven als cardiale bijwerking van de tweedelijns hormonale therapie, en is perifeer oedeem beschreven in een aantal casereports op basis van hypocalciëmie als gevolg van behandeling met bisfosfonaten en denosumab [18, 19]. Hoewel uit de dagelijkse praktijk bekend is dat perifeer lymfoedeem ook bij patiënten met een gemetastaseerd prostaatcarcinoom regelmatig voorkomt en wel degelijk tot problemen kan leiden (pijn en verminderde mobiliteit), hebben we daarover in de literatuur geen specifieke gegevens gevonden.

\section{Mictieklachten}

Ruim 55\% van de patiënten met een gemetastaseerd prostaatcarcinoom, die geen behandeling van de primaire prostaattumor hebben gehad, ontwikkelt hinderlijke mictieklachten ten gevolge van lokale tumorprogressie [20]. Bij patiënten die wel eerder behandeld zijn (radicale prostatectomie of uitwendige bestraling), ligt dat percentage significant lager (33\%), waarbij patiënten die eerder een radicale prostatectomie ondergingen minder mictieklachten ontwikkelen dan patiënten die met lokale radiotherapie zijn behandeld. Uit een kleine studie die is gebaseerd op de uitkomsten van urodynamisch onderzoek komt naar voren dat patiënten met gemetastaseerd prostaatcarcinoom en hinderlijke LUTS, deze LUTS bij slechts $14 \%$ van de patiënten overwegend en bij nog eens $14 \%$ van de patiënten deels wordt veroorzaakt door blaasontledigingsstoornissen ten gevolge van obstructie. Daarentegen was bij 57\% van de patiënten sprake van detrusoroveractiviteit zonder obstructieve component, die mogelijk gerelateerd was aan een verminderde blaascapaciteit dan wel lokale doorgroei in het trigonum [21]. De literatuur hierover is echter uiterst beperkt, het aantal gerapporteerde patiënten klein en de variatie in uitkomst groot.

\section{Pijn}

Bij 50-90\% van de patiënten met een gemetastaseerd prostaatcarcinoom, speelt pijn een evidente rol en heeft deze 
pijn een grote invloed op de ervaren algehele kwaliteit van leven. De pijn wordt veelal veroorzaakt door:

- directe (door)groei van de tumor of metastasen (77\%), met pijn als het gevolg van:

- botmetastasen (lokale botdestructie, fractuur, uitbreiding naar de weke delen, compressie van ruggenmerg of wortels);

- infiltratie van de weke delen;

- infiltratie van ingewanden (bijvoorbeeld darm, lever);

- compressie of infiltratie van zenuwen of zenuwplexus;

- diagnostische procedures;

- behandelingen (chirurgie, radiotherapie, chemotherapie);

- bijkomende factoren (bijvoorbeeld obstipatie, decubitus, spierspasmen, infectie) of niet aan de maligniteit gerelateerde comorbiditeit.

Aan pijn door kanker liggen verschillende mechanismen ten grondslag, die relevant zijn bij de keuze van de analgetische strategie. De onderverdeling tussen nociceptieve en neuropathische pijn is van belang gezien de keuze van het type analgeticum. Nociceptieve (somatische en viscerale) pijn treedt op door weefselbeschadiging. Neuropathische pijn treedt op door beschadiging van het somatosensorische systeem, dat begint bij de primaire afferente neuronen en eindigt in de somatosensorische cortex.

Naast fysieke pijn als symptoom van tumorgroei, is er een evidente wederkerige relatie tussen angst, depressieve gedachten en boosheid enerzijds en de pijnbeleving anderzijds. Pijn dient dan ook niet alleen volgens het monodimensionele biomedische model geduid te worden, maar meer binnen het concept van total pain, waarbij psychosociale en spirituele factoren een essentiële rol spelen bij de pijnbeleving.

Tot slot is de frequent aanwezige comorbiditeit en bijkomende polyfarmacie een belangrijke oorzaak van een onvoldoende positief effect van pijnbehandeling. Recentelijk is een opmerkelijke interactie beschreven tussen enzalutamide, als sterke inductor van het cytochroom-P450-systeem, en onder andere fentanyl. De enzalutamide leidt tot een versterkt metabolisatie, waardoor het pijnstillende effect van fentanyl sterk afneemt en de pijnbehandeling daardoor mogelijk onvoldoende is [22].

\section{Symptomatische hydronefrose (postrenaal)}

Ongeveer 5-15\% van de patiënten met gemetastaseerd prostaatcarcinoom krijgt te maken met obstructie van één of beide ureteren, al dan symptomatisch (pijn, infectie), die mogelijk leiden tot nierfunctiestoornissen [23]. Over het algemeen wordt deze obstructie veroorzaakt door lokale doorgroei, massawerking van het primaire proces of door lymfekliermetastasen. Metastasen van het prostaatcarcinoom in de ureter worden alleen in casereports beschreven [24]. Er zijn geen gegevens bekend over de frequentie waarmee hiervoor interventies (nefrodrain, JJ-katheter, operatie) worden toegepast. Evenmin zijn er in de literatuur overtuigende gegevens over de waarde van lokale behandeling van de prostaat (operatie/radiotherapie) ter preventie van, dan wel directe behandeling van, de hydronefrose ten gevolge van obstructie van de distale ureteren door lokale tumorprogressie $[20,25,26]$.

\section{Vermoeidheid}

Vermoeidheid is een zeer frequent voorkomende klacht bij patiënten met een (gemetastaseerd) (prostaat)carcinoom. In de literatuur varieert het percentage oncologische patiënten bij wie (ernstige) vermoeidheid voorkomt van 19-66\%. De etiologie van vermoeidheid is divers en kan voorkomen ten gevolge van de ziekte zelf, de behandeling, anemie, ouderdom, een a priori slechte conditie of psychogene factoren (stress, depressie, angst). Daarnaast kan vermoeidheid secundair zijn aan klachten, en dan met name pijn en misselijkheid. Vaak zijn de oorzaken multifactorieel en is niet altijd goed te achterhalen wat de exacte oorzaak van de vermoeidheid is. Wel is bekend dat vermoeidheid de belangrijkste factor is bij een mindere algehele kwaliteit van leven, een slechtere mentale gesteldheid en meer psychologische stress [27]. Meer specifiek voor prostaatkanker is de ernstige (graad 3-4) vermoeidheid die wordt gerapporteerd als bijwerking van de tweedelijns hormonale therapieën (abiraterone/enzalutamide) en dan voornamelijk wanneer deze medicatie wordt toegediend aan chemotherapienaïeve patiënten [28].

\section{Resultaten van twee Nederlandse prospectieve studies}

\section{Registratiestudie 2004}

In 2004 is in Nederland een prospectieve studie gestart naar de klinische karakteristieken van patiënten bij wie in dat jaar een prostaatcarcinoom is vastgesteld en het behandelingspatroon bij deze patiënten. Dertig ziekenhuizen hebben in deze studie geparticipeerd, waarbij in totaal 2.714 patiënten zijn geïncludeerd, van wie $12 \%(n=316)$ een primair ossaal gemetastaseerd prostaatcarcinoom had.

Van de geïncludeerde patiënten is in 2009 (retrospectief) het klinisch beloop onderzocht [29]. Hierbij zijn onder andere geregistreerd: tijd tot progressie (biochemisch, objectief), overleving, oorzaak overlijden, PSA-nadir, secundaire hormonale manipulaties, aantal en aard fracturen, antal (incomplete) dwarslaesies, ziekenhuisopnamen en palliatieve behandelingen. Statische analyses zijn goeddeels descriptief. Met behulp van Kaplan-Meier en Cox- 
regressieanalyses zijn overleving en prognostische factoren berekend en prognostische modellen opgesteld.

\section{Resultaten}

- Geïncludeerde patiënten: $n=254$; van 62 patiënten was het niet mogelijk voldoende betrouwbare gegevens te achterhalen.

- Karakteristieken: Leeftijd (mediaan) 73 jaar (spreiding 68-79), PSA-mediaan $146 \mathrm{ng} / \mathrm{ml}$ (spreiding 46461), PS 0 (50\% van de patiënten), pijnscore 0 (60\%), Charlson Index 0 (45\%).

- Klinisch beloop: $10 \%$ van de patiënten kreeg een fractuur en $1 \%$ twee fracturen. Bij drie patiënten was sprake van een spontane fractuur. De fractuur werd veroorzaakt door een metastase (75\%), osteoporose (4\%) of was het gevolg van een trauma waarbij een fractuur optrad van een nietpathologisch bot (21\%). Het merendeel van de fracturen betrof de heup (60\%) of een wervel (20\%). Bij 61\% van de patiënten was chirurgisch ingrijpen noodzakelijk.

- $10 \%$ van de patiënten ontwikkelde compressie van het myelum of een zenuwwortel, die leidde tot een (in)complete dwarslaesie: bij 39\% van hen door een traumatische wervelfractuur en bij de anderen door lokale progressie van metastasen met compressie. Op twee na alle wervelfracturen waren pathologisch (metastasen): bij één patiënt was de wervelfractuur het gevolg van osteoporose en bij een andere patiënt trad de wervelfractuur op bij normale botdichtheid.

- Ziekenhuisopnamen: eenmalig (70\%), tweemaal (32\%), driemaal (15\%), viermaal (5\%) en vijfmaal (2\%). Reden voor ziekenhuisopnamen waren: anemie, fractuur, (in)complete dwarslaesie, mictieklachten, pijn en/of algehele malaise.

- Palliatieve behandelingen:

- externe radiotherapie van de pijnlijke metastasen: één behandeling (43\%), twee behandelingen (18\%), drie behandelingen $(8 \%)$, vier behandelingen $(4 \%)$, vijf behandelingen (3\%);

- behandeling met radionucliden (11\%);

- chemotherapie (19\%);

- bisfosfonaten (25\%).

- Overleving: mediane tijd tot biochemische progressie voor de gehele groep 18 maanden, overleving 27 maanden.

- Onafhankelijke prognostische factoren voor overleving: differentiatiegraad van de tumor, het aantal botmetastasen, de performance status en de PSA-nadir.

Op basis van de onafhankelijke prognostische factoren is een prognostisch model voor overleving geconstrueerd. Volgens dit model is de mediane overleving 13 maanden bij een G3-tumor, een PS $>1$, meer dan 15 botmetastasen en een PSA-nadir $>75 \%$, terwijl de mediane overleving 44 maanden is bij een patiënt met een G1-2-tumor, minder dan 5 botmetastasen, PS van $0-1$ en een PSA-nadir $<25 \%$. Opmerkelijk is dat de hoogte van het initiële PSA en de leeftijd geen onafhankelijke prognostische factoren zijn. Oorzaak van overlijden is het prostaatcarcinoom bij $70 \%$ van de patiënten.

\section{HORRAD-studie}

In 2018 zijn de resultaten gepresenteerd van de HORRAD-studie, een prospectieve gerandomiseerde studie bij patiënten met een primair ossaal gemetastaseerd prostaatcarcinoom die behandeld zijn met standaard hormonale therapie of met standaard hormonale therapie gecombineerd met radicale externe radiotherapie op de prostaat (zie ook artikel elders in dit tijdschrift) [30, 31]. Van deze studie is ook het klinisch beloop van patiënten geregistreerd. In het totaal zijn 446 patiënten geïncludeerd. Een deel van de patiëntenpopulatie is nog in leven en van een deel zijn de data nog niet bewerkt. In dit artikel worden dus alleen de resultaten gepresenteerd van de interimanalyse van 311 patiënten. Deze analyse betreft een aantal patiëntkarakteristieken, de frequentie van het aantal tweedelijnsbehandelingen en de frequentie van de aan de ziekteprogressie gerelateerde problemen (lokale obstructie, anemie, fracturen, (in)complete dwarslaesies, palliatieve radiotherapie en ziekenhuisopnamen). Tot slot hebben we de correlaties geanalyseerd tussen deze problemen en de overleving, vanuit de klinische observatie dat patiënten tegenwoordig als gevolg van de tweedelijns behandeling weliswaar langer leven, maar die langere overleving wel gepaard gaat met meer klachten en problemen.

\section{Resultaten}

- Karakteristieken: leeftijd mediaan 67 (spreiding 62-72), PSA mediaan $132 \mathrm{ng} / \mathrm{ml}$ (spreiding 53-474), PS 0 (85\%), pijnscore $0(65 \%) .47 \%$ van de patiënten heeft gedurende het ziektebeloop geen aanvullende tweedelijns behandeling gehad in de zin van chemotherapie (docetaxel, cabazitaxel, overig), tweedelijns hormonale handeling (abiraterone, enzalutamide) of radium-223. 53\% heeft variërend van één tot maximaal vijf adjuvante tweedelijns therapieën gehad.

- Pathologische fractuur: deze trad op bij $14 \%$ van de patiënten (waarvan 60\% heupfractuur). Een (in)complete dwarslaesie ten gevolge van een wervelfractuur dan wel doorgroei van een metastase met compressie van het ruggenmerg of de wortel trad op bij 14\% van de patiënten.

- Mictieklachten in de zin van blaasontledigingsstoornissen waarvoor clean intermittent self catheterisation 
(CIC), een catheter à demeure (CAD), een suprapubische katheter (SP) of een transurethrale resectie van de prostaat (TURP) noodzakelijk is: $23 \%$.

- Nierinsufficiëntie bij hydronefrose op basis van ureterobstructie ten gevolge van lokale tumorprogressie waarvoor een nefrodrain of JJ-katheter nodig is: $5 \%$

- Anemie waarvoor bloedtransfusie nodig is: $34 \%$. Van hen kreeg $42 \%$ één transfusie, $17 \%$ twee en $41 \%$ drie tot acht transfusies.

- Ziekenhuisopnamen: $76 \%$ van de patiënten is een of meerdere malen opgenomen in verband met aan de prostaatkanker gerelateerde problemen: eenmalig (33\%), twee keer (26\%) 3-15 keer (41\%).

- Palliatieve radiotherapie: $55 \%$ van de patiënten is aanvullend palliatief radiotherapeutisch behandeld op pijnlijke metastasen, van wie $36 \%$ eenmalig, $29 \%$ tweemaal en $35 \%$ drie- tot negenmaal.

- Aanvullende behandeling met radionuclide vond plaats bij $12 \%$ van de patiënten.

- Overleving: De mediane tijd tot biochemische progressie en overleving voor de gehele groep was respectievelijk 14 en 44 maanden.

Interimanalyses (Spearmans-rankcorrelaties) laten een significant verband zien tussen de overlevingsduur en de frequentie van ziekenhuisopnamen, klachten ten gevolge van lokale progressie, bloedtransfusies en palliatieve radiotherapie.

\section{Beknopt overzicht van de palliatieve therapeutische mogelijkheden}

Zoals beschreven is de etiologie van problemen die patiënten met een gemetastaseerd prostaatcarcinoom in het beloop van hun ziekte ervaren in vele gevallen breed. Het is van belang om altijd zo goed mogelijk de oorzaak van de problemen te achterhalen teneinde een zo gericht mogelijke behandeling te kunnen geven. Hierna volgt een overzicht van de meest gangbare behandelingen. Dit overzicht beoogt niet compleet te zijn, maar wel praktisch.

\section{Anemie}

Alvorens een patiënt met een anemie transfusiebehoeftig is, kan gestart worden met meer conservatieve behandeling als erytropoësestimulerende middelen, suppletie van ijzer, vitamine $\mathrm{B}_{12}$ en foliumzuur. Dexamethason in lage dosering $(0,5-2,0 \mathrm{mg} 1 \mathrm{dd} 1)$ leidt ook tot een toename van het $\mathrm{Hb}$-gehalte [32]. Omdat de beenmergreserve bij de meeste patiënten niet voldoende is, zullen deze behandelingen mogelijk niet voldoende effectief zijn. Een bloedtransfusie zal al snel de enige effectieve behandeling zijn bij patiënten met een symptomatische anemie, met een duidelijke verbetering van de kwaliteit van leven tot gevolg.

\section{Dwarslaesie (incompleet/compleet)}

Indien patiënten zich melden met klachten (pijn, radiculair syndroom, sensibele en/of motorische uitval, caudasyndroom) die kunnen duiden op een (in)complete dwarslaesie is een multidisciplinaire aanpak aangewezen. Er dient nauw overleg te zijn tussen uroloog, neuroloog, radioloog, radiotherapeut en orthopeed/neurochirurg, bij voorkeur volgens een vast lokaal protocol. Indien de diagnose (in)complete dwarslaesie ten gevolge van een metastase prostaatcarcinoom wordt gesteld (neuroloog/radioloog), is het aan de uroloog om vast te stellen wat de levensverwachting van de patiënt is. Er dient direct gestart te worden met een bolus van $10 \mathrm{mg}$ dexamethason i.v. gevolgd door $8-16 \mathrm{mg}$ dexamethason per os. Externe radiotherapie is de behandeling van eerste keuze, mits het mogelijk is om een adequate dosis te geven (cave status na eerdere radiotherapeutische behandelingen) en er geen indicatie is voor chirurgie. Een eenmalige dosis van $8 \mathrm{~Gy}$ is in Nederland het meest gebruikt. Radiotherapie leidt echter niet tot een directe drukvermindering. Chirurgie en dexamethason kunnen wel tot drukvermindering leiden. Chirurgie is de behandeling van eerste keuze indien de levensverwachting langer is dan drie maanden, een directe decompressie nodig geacht wordt, er sprake is van instabiliteit van de wervelkolom, radiotherapie niet meer mogelijk is, of indien er neurologische achteruitgang is onder behandeling met radiotherapie/ corticosteroïden. Logischerwijze moet de patiënt operabel zijn, de operatie technisch mogelijk zijn en logistiek op korte termijn (bij voorkeur $<24$ uur) uitgevoerd kunnen worden. Indien de patiënt aan de indicaties en voorwaarden van zowel radiotherapie als chirurgie voldoet, zal op basis van het multidisciplinaire overleg in directe samenspraak met de patiënt een therapiekeuze gemaakt worden. Indien een operatie is uitgevoerd met alleen een decompressie, en er dus geen totale tumorresectie heeft plaatsgevonden, dient de patiënt 2-4 weken postoperatief lokaal nabestraald te worden. De resultaten van chirurgie zijn goed en leiden tot minder pijn, een betere mobiliteit en een betere mentale en algehele kwaliteit van leven. Persisterende neurologische uitval is geassocieerd met een kortere levensverwachting. Dergelijke uitval dient bij voorkeur voorkomen te worden en -indien ze wel optreedt - zo snel mogelijk adequaat behandeld te worden teneinde een optimale kans op herstel te bieden $[13,33,34]$.

\section{Fracturen}

Een belangrijke pijler in de behandeling is de preventie van fracturen. Er bestaat overtuigend bewijs dat behandeling 
met vitamine $\mathrm{D}$ en calcium in combinatie met een bisfosfonaat of denosumab de kans op het optreden van osteoporose ten gevolge van de hormonale behandeling en daarmee de kans op het optreden van fracturen reduceert [35]. Daarentegen laat een Cochrane meta-analyse onvoldoende bewijs zien dat behandeling met bisfosfonaten de kans op het optreden van pijn en/of fracturen ten gevolge van metastasen reduceert. Evenmin wordt een betere overleving aangetoond [36]. Er zijn publicaties die onder meer op basis van de T-score (botdichtheid <2,5) leeftijd (>7 5), BMI $(<19)$, comorbiditeit ( $>2$, waaronder cardiovasculair) en een verhoogde valneiging patiënten selecteren die in aanmerking komen voor medicamenteuze behandeling [37]. Gezien het bescheiden bijwerkingenprofiel van de voor te schrijven medicatie en het feit dat de grootste groep patiënten ook bij voornoemde selectie behandeld moet worden, lijkt het vooral praktisch om alle patiënten met een gemetastaseerd prostaatcarcinoom die continu hormonaal behandeld worden, ook te behandelen met vitamine $\mathrm{D} /$ calcium en een bisfosfonaat of denosumab.

Verder is het van belang om aandacht te hebben voor een eventuele verhoogde valneiging bij deze patiënten (door onder meer duizeligheid, evenwichtsstoornissen, medicatie, 'slecht ter been zijn'), wat goed beoordeeld kan worden door de oncologieverpleegkundige. Gerichte interventies waaronder bijvoorbeeld lopen met een rollator, aanpassingen in huis en samen met de huisarts de medicatie aanpassen, zijn uiterst zinvol. Het voorkomen van fracturen leidt tot minder pijn, een betere kwaliteit van leven en een betere overleving [38].

Indien er toch een fractuur optreedt en de levensverwachting langer is dan drie maanden, moet primair een chirurgische interventie overwogen worden. Zo'n interventie leidt in ieder geval tot minder pijn en een betere kwaliteit van leven. In de literatuur hebben we niet kunnen vinden of het de overleving ook beïnvloedt. Indien er geen oncologische (radicale) resectie is geweest, dient ongeveer 2-4 weken na de operatie de behandelde fractuur nabestraald te worden ter preventie van lokale progressie, waarbij een kortdurend schema meestal volstaat. Indien opereren om wat voor een reden dan ook niet kan, is bestraling voor de bestrijding van pijn aangewezen.

\section{Hematurie}

Logischerwijs zijn urologen bekend met de primaire behandeling van hematurie, waaronder het inbrengen van een spoelkatheter en het spoelen van de blaas. Als medicamenteuze behandeling van hematurie beschrijft de literatuur tranexaminezuur 3 dd $1000 \mathrm{mg}$ oraal (echter niet bij massale hematurie en/of aanwezigheid van stolsels vanwege de toegenomen kans op stolselvorming), of aluin 0,5-1\% blaasspoelingen. De effectiviteit van deze behandelingen is echter onduidelijk. Indien de hematurie persisteert en wordt veroorzaakt door lokale progressie of lokale bloedende laesies in de blaas, is operatief ingrijpen in de vorm van transurethrale coagulatie of resectie zinvol [39]. Palliatieve uitwendige bestraling op de prostaat behoort eveneens tot de behandelopties als voornoemde mogelijkheden niet effectief blijken.

Indien een radiatiecystitis oorzaak is van persisterende hematurie is behandeling met hyperbare zuurstoftherapie succesvol bij 50-80\% van de patiënten [40, 41].

Als geen van deze behandelingen effectief is en de bloedtransfusiebehoeftige hematurie blijft bestaan, kan besloten worden tot een radiologische embolisatie van de arteria prostatica en in uitzonderlijke gevallen zelfs tot een palliatieve (cysto)prostatectomie [42]. Uiteraard dient een stollingsstoornis of een trombopenie te worden gecorrigeerd; bij gebruik van antistolling dient deze medicatie, in overleg met de voorschrijvend behandelaar, zo mogelijk te worden gestaakt.

\section{Mictieklachten}

De algehele conditie en levensverwachting van de patiënt zal het beleid ten aanzien van mictieklachten sterk bepalen. De work-up van patiënten met mictieklachten bij prostaatcarcinoom is vergelijkbaar met die van patiënten met benigne prostaathyperplasie (BPH) en kan worden toevertrouwd aan een uroloog. Indien de klachten berusten op een blaasontledigingsstoornis dient deze stoornis primair medicamenteus behandeld te worden (alfablokkers). Bij onvoldoende resultaat is een palliatieve TURP een goed alternatief met succespercentages tot $90 \%$ en acceptabele complicaties die vergelijkbaar zijn met die van een TURP voor BPH [43]. Indien ook die behandeling onvoldoende effect heeft of indien een patiënt niet meer geopereerd kan of wil worden rest, zeker bij forse residuvorming of retentie, CIC, of een permanente transurethrale of suprapubische katheter.

Indien opslagklachten meer op de voorgrond staan, al dan niet bewezen met een urodynamisch onderzoek, kan gestart worden met de bekende anticholinergica. Tot slot kan een medicamenteuze combinatiebehandeling (alfablokker met anticholinergica) succesvol zijn.

\section{Pijn}

Een mooi en handzaam overzicht van de pijnbestrijding bij patiënten met kanker is te vinden op www.pallialine.nl onderdeel van de IKNL-richtlijnen [44].

Behandel volgens het concept van total pain en schenk bij behandeling van pijn ook aandacht aan de lichamelijke, cognitieve, emotionele, gedragsmatige en sociale aspecten die een rol spelen bij de pijnbeleving. Het is belangrijk om 
te weten in hoeverre de pijn interfereert met het dagelijks leven. Bevorder de therapietrouw door goede voorlichting omtrent het doel en de mogelijke bijwerkingen van de behandeling, bespreek verwachtingen en mogelijke weerstanden, benadruk het belang van regelmatige inname van de medicatie, ook als er geen pijn is, en onderstreep het feit dat verslaving klinisch minder relevant is [45].

Een systematische medicamenteuze behandeling van pijn is gebaseerd op de gemodificeerde WHO-pijnladder en bevat op hoofdlijnen de volgende stappen bij nociceptieve pijn:

1. Paracetamol 4 dd 500-1000mg p.o. of 3-4 dd $1000 \mathrm{mg}$ supp. \pm NSAID (niet bij nierfunctiestoornissen): diclofenac tot $4 \mathrm{dd} 50 \mathrm{mg}$ p.o. of rectaal, naproxen tot $2 \mathrm{dd}$ $500 \mathrm{mg}$ p.o. of rectaal, of ibuprofen tot $4 \mathrm{dd} 600 \mathrm{mg}$ p.o. of $4 \mathrm{dd} 500 \mathrm{mg}$ rectaal.

2. Morfine slow release (startdosis: $2 \mathrm{dd} 20 \mathrm{mg}$, bij patiënten $>70$ jaar $2 \mathrm{dd} 10 \mathrm{mg}$ ) of fentanyl transdermaal $12 \mu \mathrm{g} / \mathrm{uur}$ : eventueel in combinatie met paracetamol en/of NSAID's, altijd in combinatie met een snelwerkend opioïd voor doorbraakpijn (oxycodon). Daarnaast altijd een laxans voorschrijven (macrogol/elektrolyten 1-2 sachets dd of magnesium(hydr)oxide 3 dd 500-1000 mg).

3. Opioïdrotatie (zie de omrekentabel opioïden in de IKNLrichtlijn [44]) bij onvoldoende effect van het opioïd ondanks aanpassing van de dosis, toedieningsfrequentie en toedieningsweg en/of bij onaanvaardbare bijwerkingen: morfine vervangen door fentanylpleister of vice versa eventueel oxycodon slow release 2 dd of hydromorfon slow release $2 \mathrm{dd}$.

En bij neuropathische pijn, eveneens gebaseerd op de gemodificeerde WHO-pijnladder, de volgende stappen:

1. Opiö̈den als bij stap 2 voor nociceptieve pijn (alsmede tramadol 4 dd 50-100mg). Bij zuiver neuropathische pijn kan deze stap in eerste instantie worden overgeslagen; eventueel kan dan in een later stadium (bij onvoldoende effect op de hierna genoemde middelen) een opioïd worden toegevoegd.

2. Amitriptyline of nortriptyline: startdosis $10-25 \mathrm{mg}$ p.o. voor de nacht, zo nodig op te hogen met stappen van $25 \mathrm{mg}$ per 3-7 dagen tot maximaal $75 \mathrm{mg}$ voor de nacht.

Bij gelokaliseerde pijn die wordt veroorzaakt door een botmetastase is eenmalige $(1 \times 8 \mathrm{~Gy})$ externe radiotherapie zeer effectief, met bij ongeveer $70 \%$ van de patiënten een afname van de klachten van 70\% [46-49]. De eerste dagen na de bestraling kan de pijn tijdelijk iets heviger worden. De afname van de pijn kan optreden tot zes weken na de behandeling. De bestraling van dezelfde metastase kan nog een- tot tweemaal herhaald worden met tussenpozen van minimaal zes weken. Bij meerdere ( $>3$ ) pijnlijke botmetastasen is behandeling met radionucliden (strontium en sa- marium-153) effectief bij 60-80\% van de patiënten [50]. Ook de palliatieve pijnbestrijding met een radionuclide kan in voorkomende gevallen meerdere malen worden ingezet. De voorkeur gaat uit naar samarium, omdat dit middel sneller werkt en zo nodig iedere maand herhaald kan worden.

Primair doel is patiënten zo veel mogelijk pijnvrij te krijgen, hoewel dat niet altijd mogelijk zal zijn. Indien het niet lukt om patiënten met voornoemde middelen binnen enkele weken in een acceptabele situatie te krijgen (bij voorkeur pijnvrij), is verwijzing naar een gespecialiseerd pijnteam aangewezen. Daar zit niet alleen de kennis voor veel uitgebreidere en complexere medicamenteuze behandeling, maar ook de kunde voor interventionele behandelingen (pijnblokkades), waaronder de neurolytische (fenol/ alcohol)infiltratie van de plexus hypogastricus inferior en van het ganglion van Walther (impar). De eerste ligt anterieur van de wervelcorpora L5-S1 en laatste anterieur ter hoogte van de sacro-coccygeale overgang. Beide technieken zijn laagcomplex, eenvoudig en onderbreken de sympathische grensstreng, met als gevolg een onderbreking van afferente stimuli die verantwoordelijk zijn voor de sympathisch gemedieerde neuropathische en viscerale pijn bij ruimte-innemende processen en metastasen in het kleine bekken.

Hoewel invasieve behandeling vaak als laatste type pijnbehandeling in de WHO-pijnladder beschreven wordt, dienen deze bij voorkeur niet als last resort ingezet te worden, gezien het opioïdsparende effect en de daarmee gepaarde verbetering van kwaliteit van leven van dergelijke interventies.

\section{Lymfoedeem}

De conservatieve behandeling van lymfoedeem (decongestieve lymfatische behandeling (DLT)) is zowel gericht op het voorkomen van progressie (de preventie) als op vermindering van de gevolgen van lymfoedeem (de therapeutische behandeling). DLT omvat: compressietherapie (CT), manuele lymfedrainage (MLD), oefentherapie/beweging en voorlichting met ondersteunende zorg gericht op risicoreductie [17]. Verwijzing hiervoor naar een gespecialiseerde fysiotherapeut is aangewezen. Indien het lymfoedeem wordt veroorzaakt door progressie van locoregionale lymfekliermetastasen kan, indien mogelijk, palliatieve externe radiotherapie zinvol zijn. Als het (lymf)oedeem wordt veroorzaakt door veneuze afvloedbelemmering ten gevolge van veneuze compressie (bijvoorbeeld door lymfadenopathie) is het plaatsen van een veneuze stent (vena Iliaca communis/externa) door de interventieradioloog uiterst effectief en is het oedeem binnen enkele dagen geheel verdwenen. 


\section{Symptomatische hydronefrose}

Bij hydronefrose met klachten van flankpijn die al dan niet gepaard gaan met koorts en/of nierfunctiestoornissen is drainage door middel van een nefrodrain of JJ-katheter geïndiceerd. Gezien mogelijke compressie van de JJ-katheter geniet een nefrodrain de voorkeur. Na het plaatsen van een nefrodrain behoort het antegraad plaatsen (eventueel na dilatatie van de distale ureter) van een JJ-katheter, door de interventieradioloog, tot de mogelijkheden. Daarnaast kan lokale palliatieve radiotherapie of chirurgie (ureter reimplantatie) overwogen worden in een poging de doorgankelijkheid van de distale ureter te herstellen.

\section{Vermoeidheid}

Als de patiënt klaagt over (ernstige, invaliderende) vermoeidheid dient allereerst uitgesloten te worden dat er sprake is van anemie en vervolgens beoordeeld te worden of de vermoeidheid kan samenhangen met tweedelijns (hormonale) therapie. In voornoemde gevallen is een bloedtransfusie aangewezen, dan wel het (tijdelijk) staken van de tweedelijns behandeling, in overleg met patiënt. Indien er sprake is van pijn of misselijkheid als medeoorzaak van de vermoeidheid, moet die behandeld worden. Daarnaast is er afdoende wetenschappelijk bewijs dat dagelijkse gestructureerde lichamelijke inspanning (waaronder gym, oncofysiotherapie, lopen) een significante reductie van de vermoeidheid, een toename van de vitaliteit en een betere algehele kwaliteit van leven en mentaal welbevinden geeft $[51,52]$. Tot slot is gedragstherapie teneinde te leren omgaan met de vermoeidheid bij prostaatkanker zinvol gebleken. De patiënt kan hiervoor verwezen worden naar gespecialiseerde psychologen/gedragstherapeuten of instituten zoals het Helen Dowling Instituut in Utrecht.

\section{Discussie}

Het gemetastaseerd prostaatcarcinoom komt wereldwijd uiterst frequent voor. De laatste jaren is er bijzonder veel aandacht voor het lokaal uitgebreide en gemetastaseerd prostaatcarcinoom. Nieuwe behandelingsstrategieën zijn in ontwikkeling; er zijn thans meerdere tweedelijns therapieën voor het castratieresistente prostaatcarcinoom en in de toekomst komt nieuwe medicamenteuze therapie beschikbaar, waaronder doelgerichte therapie en immuuntherapie. Mede door deze ontwikkelingen is er veel aandacht voor het prostaatcarcinoom, niet alleen bij urologen, maar ook bij oncologen, radiotherapeuten, radiologen en tal van andere hulpverleners. Toch lijkt er meer aandacht voor nieuwe diagnostische en behandelingsmodaliteiten dan voor het klinisch beloop. Opmerkelijk genoeg zijn er nauwelijks adequate gegevens beschikbaar over het klinisch beloop bij patiënten met een gemetastaseerd prostaatcarcinoom. Welke problemen doen zich bijvoorbeeld voor tijdens het ziektebeloop en hoe frequent?

In dit artikel hebben we een overzicht gegeven van de beperkte literatuur die er is. Daarnaast zijn de (interim)resultaten gepresenteerd van twee studies waarin het beloop bij deze patiëntengroep in kaart is gebracht. De gecombineerde resultaten van deze studies geven het volgende beeld:

- $10-15 \%$ van de patiënten krijgt een fractuur;

- 10-15\% ontwikkelt een (in)complete dwarslaesie;

- $25 \%$ krijgt blaasontledigingsstoornissen waarvoor CIC, een CAD, een SP of een TURP noodzakelijk is;

- 5\% krijgt een symptomatische hydronefrose (nierinsufficiëntie, pijn, infectie) als gevolg van obstructie van de distale ureter waarvoor een nefrodrain of JJ noodzakelijk is;

- $35 \%$ anemie waarvoor één of meerdere bloedtransfusies noodzakelijk zijn;

- 75\% van de patiënten wordt één of meerdere malen opgenomen voor behandeling van aan de progressieve prostaatkanker gerelateerde problemen;

- $55 \%$ van de patiënten wordt één of meerdere malen palliatief bestraald op (pijnlijke) bot metastasen.

Hieruit wordt duidelijk dat de klachten en problemen waarmee patiënten gedurende het beloop van hun ziekte geconfronteerd worden aanzienlijk zijn en door hun aard een grote impact hebben op de algehele kwaliteit van leven. Omdat deze patiënten niet meer genezen kunnen worden, dient de behandeling niet alleen gericht te zijn op het verlengen van het leven, maar nadrukkelijk ook op tijdige en adequate behandeling van de aan de ziekteprogressie gerelateerde problemen. Kennis van die problemen en vroegtijdige herkenning daarvan, gecombineerd met de mogelijkheden tot gerichte behandeling zijn dan ook voorwaardelijk. Zoals geschetst zijn de problemen zo divers en complex dat aan deze voorwaarden alleen voldaan kan worden door een team van toegewijde professionals waaronder in ieder geval een uroloog, oncoloog, radiotherapeut, radioloog, neuroloog, orthopeed/neurochirurg, oncologie verpleegkundig, fysiotherapeut en psycholoog/psychiater. Vanzelfsprekend moet voor de patiënt duidelijk zijn wie de hoofdbehandelaar is, die in geval van problemen altijd benaderd kan worden en garant staat voor een adequate organisatie van de zorg. Er zijn hierbij een aantal, mogelijk onderbelichte, punten van belang. Dit zijn:

- Aandacht voor vermoeidheid. Vermoeidheid is de factor die de grootste impact heeft op de algehele kwaliteit van leven, het mentale welzijn en mogelijk op de duur van overleving $[27,53]$. Toch is het een klacht die, vanuit 
de gedachte dat er weinig aan te doen is, vaak onderbelicht blijft. Neem de klacht serieus, bespreek het met de patiënt, zoek uit wat de oorzaak zou kunnen zijn, stimuleer patiënten dagelijks te bewegen (minimaal een half uur wandelen) en vraag of patiënt behoefte heeft aan ondersteunende gedragstherapie.

- Adequate pijnstilling. Ook pijn heeft een grote impact op de algehele kwaliteit van leven. Opmerkelijk genoeg accepteren veel patiënten pijn vanuit de gedachte 'dat ze nog wat achter de hand willen hebben voor als het écht nodig is'. Bespreek dat dit een onjuiste gedachte is en dat altijd gestreefd moet worden naar een pijnvrije situatie. Onderstreep dat de medicatie met name ook ingenomen moet worden als er geen pijn meer is en overweeg andere vormen van pijnbestrijding (externe radiotherapie, radionucliden, interventionele technieken) als patiënten morfinepreparaten nodig hebben. Verwijs laagdrempelig naar een pijnteam indien het niet lukt patiënten pijnvrij te krijgen met de standaard behandeling. Tot slot, enzalutamide kan de werkzaamheid van onder andere fentanyl doen afnemen, waardoor hogere doses nodig zijn. Wees er alert op dat hierdoor bij het staken van de enzalutamide een intoxicatie kan ontstaan.

- Preventie botdichtheid. Er zijn aanwijzingen dat met name urologen in vergelijking met oncologen te weinig frequent medicatie voorschrijven die de reductie van de botdichtheid voorkomen [54]. Er is voldoende bewijs dat dit effectief is en een reductie geeft van de zogenaamde aan het skelet gerelateerde klachten (pijn, fracturen). Alle patiënten die een (ossaal) gemetastaseerd prostaatcarcinoom hebben en continu, levenslang hormonaal behandeld worden, dienen aanvullend medicamenteus behandeld te worden met calcium/vitamine D in combinatie met een bisfosfonaat (bijvoorbeeld ibandroninezuur $150 \mathrm{mg} 1 \mathrm{tablet} / \mathrm{maand}$ ) of denosumab.

- Protocol voor verdenking op een dwarslaesie. In de wetenschap dat 10-15\% van de patiënten een (in)complete dwarslaesie ontwikkelt, is niet alleen een adequaat protocol, maar ook een logistieke organisatie waarbinnen alle noodzakelijke interventies (zowel diagnostisch als therapeutisch) daadwerkelijk in korte tijd kunnen worden uitgevoerd, een absolute voorwaarde. Dit betekent een neuroloog die patiënten met een mogelijke dwarslaesie of caudasyndroom direct beoordeelt, een MRI die aansluitend gemaakt en beoordeeld wordt, overleg met de betrokken specialisten (neuroloog, radioloog, uroloog, oncoloog, radiotherapeut en orthopeed/neurochirurg) om de optimale behandeling vast te stellen, én de mogelijkheid om deze behandeling (radiotherapie/operatie) ook $<24$ uur uit te voeren. Adequate opvang en behandeling van patiënten met een (in)complete dwarslaesie die leiden tot herstel, brengt niet alleen een betere kwaliteit van leven, maar ook betere overleving met zich mee. Ter illustratie een tweetal casus (zie appendix).

- Patient Reported Outcome Measures (PROMS). Er zijn aanwijzingen in de literatuur dat het structureel meten van PROMS niet alleen leidt tot een betere kwaliteit van zorg voor patiënten met een gemetastaseerde maligniteit, maar zelfs tot een betere overleving $[55,56]$. In vergelijking met de traditionele anamnese maken dergelijke gestructureerde metingen, mits regelmatig uitgevoerd, eerder zichtbaar wanneer klachten toenemen en de overall kwaliteit-van-levenparameters afnemen.

- Organisatie van de zorg. Tot slot is een goede organisatie van de zorg essentieel. Het betreft niet alleen de aanwezigheid van heldere en adequate lokale protocollen, maar ook goede afspraken tussen zorgverleners onderling. Het formeren van een vast team toegewijde professionals die een hoge zorgstandaard hanteren en die regelmatig evalueren, is noodzakelijk. De patiënt moet één aanspreekpunt hebben waar hij altijd terecht kan. Een team van oncologieverpleegkundigen die per email en telefoon bereikbaar zijn en binnen 24 uur reageren is optimaal. In acute situaties moeten patiënten op de SEH terechtkunnen. Tot slot is voor de laatste levensfase, die veelal in de thuissituatie met terminale begeleiding van de huisarts plaatsvindt, een goede overdracht van belang, eventueel door het lokale palliatief oncologisch team, met de mogelijkheid voor de huisarts om bij problemen terug te vallen op dit team.

De mediane overleving in de registratiestudie 2004 was 27 maanden; voor de hier gepresenteerde 311 patiënten uit de HORRAD-studie 44 maanden. Mede door de tweedelijnsbehandelingen is de overleving dus met anderhalf jaar toegenomen. De indruk uit de praktijk is dat deze toename gepaard gaat met meer problemen, hetgeen ook logisch lijkt vanuit het simpele oogpunt dat een langere levensduur meer kans op ziekteprogressie en de daaraan gerelateerde problemen geeft. Analyses uit de groep HORRAD-patiënten onderschrijven dit. Hieruit blijkt dat er een hoog-significante correlatie is tussen de levensduur enerzijds en de frequentie van ziekenhuisopnamen, klachten ten gevolge van lokale progressie, bloedtransfusies en palliatieve radiotherapie anderzijds. Patiënten leven dus weliswaar langer, maar dit langere leven gaat wel gepaard met aanzienlijk meer problemen. Ook dit gegeven onderstreept de noodzaak tot het leveren van goede palliatieve zorg teneinde de kwaliteit van leven van deze patiënten zo lang mogelijk op een acceptabel niveau te houden. Zeker nu er weer een tendens is dat urologen, met de nieuwe orale tweedelijnsmedicatie, zelf patiënten met een gemetastaseerd prostaatcarcinoom langer behandelen en onder controle houden, is het absoluut noodzakelijk dat deze urologen weten wat deze patiënten te wachten staat, daar alert op zijn, en een met adequate pro- 
tocollen bewapend en goed functionerend multidisciplinair team hebben geformeerd, teneinde goede palliatieve zorg te kunnen leveren.

\section{Conclusies}

Urologen worden in toenemende mate geconfronteerd met patiënten die een gemetastaseerd prostaatcarcinoom hebben. Vanzelfsprekend dienen zij op de hoogte te zijn van de therapeutische mogelijkheden die zijn gericht op het verlengen van de overleving. Echter, voor een goede behandeling en begeleiding van deze patiënten is eveneens kennis van de problemen die zich tijdens het ziektebeloop voordoen en de behandeling daarvan nodig. Dit vereist een multidisciplinaire benadering die is gebaseerd op heldere lokale protocollen, en een logistieke organisatie die op die multidisciplinaire benadering is toegesneden. Voor de patiënt is het van belang dat hij één aanspreekpunt heeft.

Dankbetuiging Met dank aan dr. Maarten C.C.M. Hulshof, radiotherapeut Amsterdam Universitair Medische Centra, Locatie AMC, dr. Diederik H.R. Kempen, orthopeed aandachtsgebied wervelkolomchirurgie, OLVG en Jeroen E. Steenhuijsen, anesthesioloog, lid pijnteam OLVG, voor hun bijdrage aan dit artikel.

Open Access This article is distributed under the terms of the Creative Commons Attribution 4.0 International License (http:// creativecommons.org/licenses/by/4.0/), which permits unrestricted use, distribution, and reproduction in any medium, provided you give appropriate credit to the original author(s) and the source, provide a link to the Creative Commons license, and indicate if changes were made.

\section{Appendix}

In het OLVG worden patiënten met een gemetastaseerd prostaatcarcinoom van oudsher multidisciplinair behandeld met de uroloog als hoofdbehandelaar. Dit betreft eveneens de problemen die zich tijdens het ziektebeloop voordoen. Jaarlijks worden hiervoor rond de 250 patiënten opgenomen op de afdeling Urologie. De zorg wordt geleverd door een team van urologen, oncologen, radiologen, neurologen, orthopeden, radiotherapeuten, oncologieverpleegkundigen en psychologen/psychiaters. Daarnaast wordt, met name bij de definitieve overdracht van de zorg naar de thuissituatie (huisarts), indien nodig, het OLVG-brede palliatief oncologisch team ingeschakeld. Gezien het grote belang voor de patiënt van vroege herkenning en adequate behandeling van wervelmetastasen, ter illustratie een tweetal ziektegeschiedenissen.

Patiënt A, een 68-jarige, uiterst actieve man die nog dagelijks fysieke zwaar werk verricht, wordt in oktober 2018 door de huisarts, primair voor de neuroloog, ingestuurd in verband met sinds drie weken bestaande progressieve loopstoornissen, verminderde kracht in beide benen, en tintelingen in beide armen en benen. De voorgeschiedenis vermeldt hypertensie en de verdere anamnese levert geen bijzonderheden op. Bij lichamelijk onderzoek wordt een vitale man gezien. Aan hart, longen en abdomen geen afwijkingen. Bij rectaal toucher een vast aanvoelende prostaat verdacht voor een T3-prostaatcarcinoom. Neurologisch onderzoek: moeizaam, spastisch looppatroon, verhoogde reflexen en bilaterale Babinski's. Aanvullend onderzoek is verricht. Laboratoriumonderzoek: $\mathrm{Hb}$ 9,0 mmol/1, eGFR $84 \mathrm{kl} / 1,73 \mathrm{~m}^{2}$, AF 119 IU/l en PSA $2165 \mathrm{ng} / \mathrm{ml}$, verder geen afwijkingen. Skeletscintigrafie: uitgebreide ossale metastasen. CT thorax/abdomen: uitgebreide regionale en extraregionale pathologische lymfeklieren verdacht voor metastasen. MRI wervelkolom: meerdere metastasen in cervicale, thoracale en lumbale wervelkolom, met ter hoogte van C5 evidente compressie op het myelum. Concluderend, een patiënt met een incomplete dwarslaesie C5 door lokale tumorprogressie op basis van de klinisch diagnose cT3N1M1a/bprostaatcarcinoom. Patiënt is direct behandeld met dexamethason i.v. en vervolgens oraal. Daarnaast is gestart met hormonale therapie, direct een antiandrogeen en een week later een LHRH analoog. De volgende dag is hij door de orthopedisch chirurg geopereerd, waarbij een spondylodese posterieur C3-Th1 (fig. 1) met decompressie C4-C7 is uitgevoerd, met uitgebreide excisie van tumorweefsel. De PA van het verwijderde weefsel laat een metastase-adenocarcinoom van de prostaat zien, Gleason $8(4+4)$ met cribriforme groei. Het direct postoperatief herstel was goed. Zeven dagen later ontwikkelt hij echter een incompleet caudasyndroom met onvermogen tot mictie en defecatie. De volgende dag wordt hij wederom geopereerd, waarbij een decompressie L3-L5 wordt uitgevoerd. Hierna wordt hij in goede conditie ontslagen. Ruim drie weken later is hij bestraald $(1 \times 8 \mathrm{~Gy})$ op C3-Th4 en L2-S2. Omdat hij nog niet fit genoeg is voor chemotherapie, wordt hij aansluitend behandeld met abiraterone/prednison met daarnaast calcichew en ibandroninezuur. Bij de laatste controle in juli 2019 vergaat het hem uitstekend. Hij is volledig hersteld, klachtenvrij en heeft zijn werkzaamheden hervat. Het PSA is $0,57 \mathrm{ng} / \mathrm{ml}$.

Patiënt $B$, een 65-jarige man met, behoudens een depressie, een blanco voorgeschiedenis wordt in april 2015 poliklinisch gezien in verband met al twee maanden bestaande progressieve heftige pijn lumbaal en in de linkerheup. De verdere anamnese levert geen bijzonderheden op. Bij onderzoek wordt een pijnlijke, uiterst moeizaam lopende man gezien. Aan hart, longen en abdomen geen afwijkingen. Rectaal toucher is verdacht voor een T4-prostaatcarcinoom. Er is drukpijn over de wervelkolom, met name laagthoracaal en bij het linkerbekken. Oriënterend neurologisch onderzoek is zonder afwijkingen. Laboratoriumonderzoek: $\mathrm{Hb} 8,6 \mathrm{mmol} / 1$, eGFR $59 \mathrm{kl} / 1,73 \mathrm{~m}^{2}$, PSA 
Figuur 1 Patiënt A: anterieure (a) en laterale (b) röntgenfoto van de spondylodese posterieur C3-Th1 met decompressie $\mathrm{C} 4-\mathrm{C} 7$
Figuur 2 Patiënt B: Dorsale (a) en laterale (b) röntgenfoto van de vertebroplastiek van het pathologische inzakkingsfractuur van Th12. De (preventieve) verlengde gamma nail in verband met het dreigende femurfractuur (c)
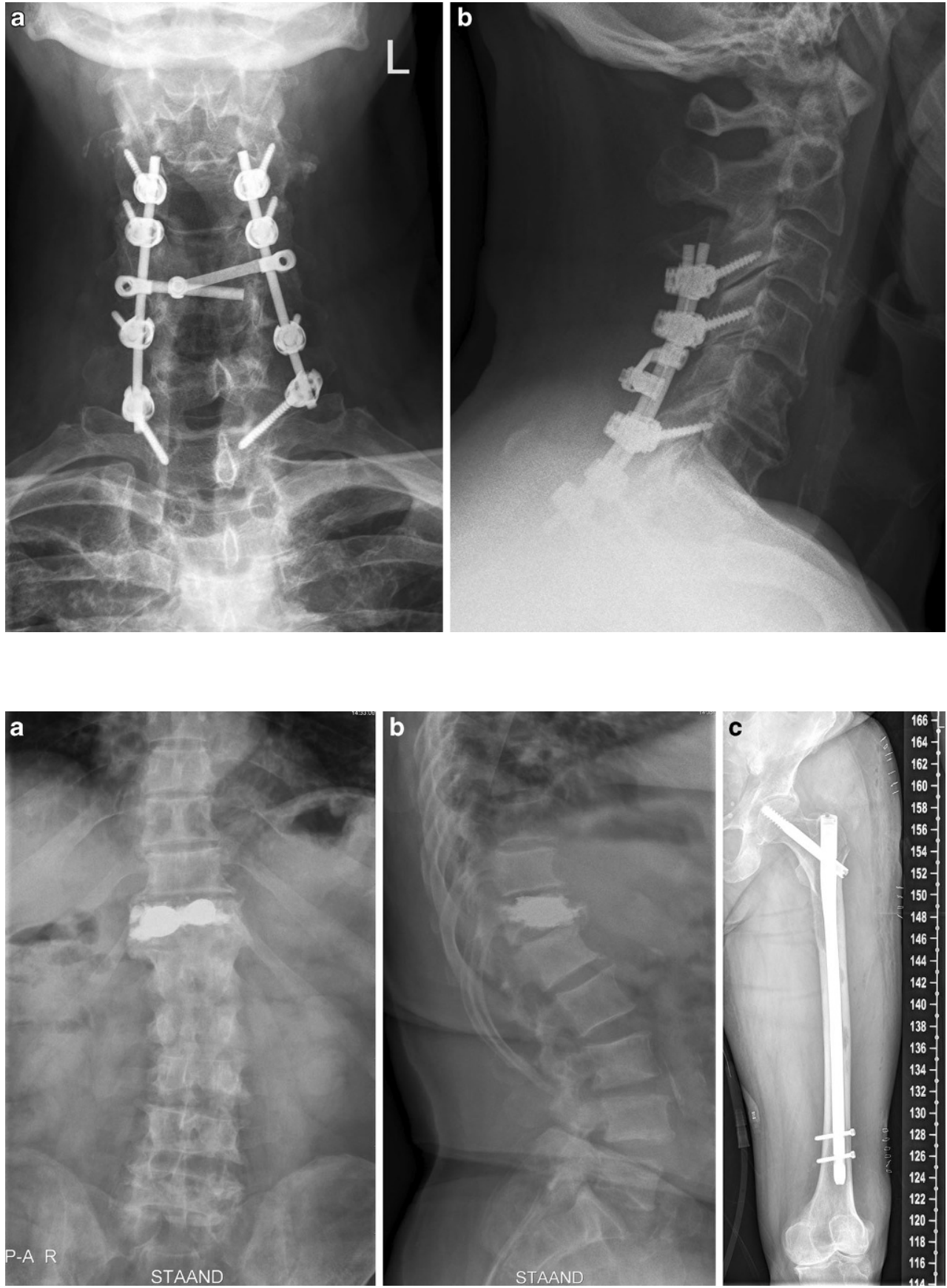

13.500 ng/ml, AF 268 IU/1. Echo prostaat: T4-prostaatcarcinoom. PA prostaatbiopten: Gleason $9(5+4)$ adenocarcinoom. Skeletscintigrafie met SPECT CT: uitgebreide ossale metastasen, één pathologische lymfeklier parailiacaal rechts, schrompelnier links. MRI wervelkolom/bekken: multipele ossale metastasen met een pathologische inzakkingsfractuur Th12, zonder compressie op het myelum of wortels. Daarnaast uitgebreide metastase linkerfemur met dreigende fractuur.

Conclusie: een patiënt met een cT4N1M1b-adenocarcinoom van de prostaat met een inzakkingsfractuur Th12 zonder neurologische uitval en een dreigende fractuur linkerfemur. Patiënt is direct hormonaal behandeld. Vervolgens is hij door de orthopeed geopereerd waarbij in één zitting een vertebroplastiek Th 12 is verricht en een verlengde gamma nail links is ingebracht (fig. 2). Patiënt is goed hersteld van de operatie. Het verdere beloop is op hoofdlijnen samengevat als volgt:

- 2015-05: externe radiotherapie proximale femur links $(1 \times 8 \mathrm{~Gy})$. 
- 2015-06: start chemotherapie (docetaxel+ prednison). In het totaal zes kuren gehad. Goed verdragen. Klinisch resultaat goed. Pijnvrij! En hij loopt weer normaal.

- 2016-10: klinisch stabiel, biochemische progressief $(\mathrm{PSA}=49$; nadir $=0,73)$. Castratieresistent. Start calcichew en ibandroninezuur.

- 2017-04: evidente biochemische (PSA=489) en klinische (vermoeid, geen pijn) progressie. Start enzalutamide.

- 2018-09: zowel klinische (vermoeid, pijn rug/ribben) als biochemische $(\mathrm{PSA}=538$; nadir $=127)$ progressie. Stop enzalutamide.

- 2018-10: PSMA PET-scan: uitgebreide ossale metastasen, geen viscerale metastasen. Start radium 223.

- 2019-02: biochemische progressie (PSA=1.506; nadir $=224$ ), maar klinisch (geen klachten) stabiel. Radium continueren. Heeft uiteindelijk zes kuren gehad. Goed verdragen en pijnvrij.

- 2019-06: biochemische (PSA = 4.979) en klinische progressie (met name vermoeid, geen substantiële pijn). Start abiraterone/prednison.

$\mathrm{Nu}$ ruim vier jaar na de initiële diagnose vergaat het patiënt nog redelijk goed. Met name de vermoeidheid speelt hem parten en dat is ook de reden dat hij vooralsnog heeft afgezien van tweedelijns chemotherapie.

\section{Literatuur}

1. Aben KKH, Oort IM van, Kiemeney LA, et al. Eindrapportage Prostaatkanker zorg in beeld (ProZIB). Utrecht: Integraal Kankercentrum Nederland; 2019.

2. Volksgezondheidenzorg.info. Prostaatkanker. Cijfers en context. 2019. www.volksgezondheidenzorg.info/onderwerp/prostaatkanker. Geraadpleegd op: 28 jun 2019.

3. Wein AJ, Kavoussi L, Partin A, Peters C. Campbell-Walsh urology. 11e druk. New York: Elsevier; 2016.

4. Nargund VH, Raghavan D, Sandler HM. Urological oncology. 2e druk. London: Springer; 2015.

5. Balaji KC. Managing metastatic prostate cancer in your urological oncology practice. Basel: Springer; 2016.

6. Kim CS. Management of advanced prostate cancer. Singapore: Springer; 2018.

7. Drudge-Coates L, Oh WK, Tombal B, Delacruz A, Tomlinson B, Ripley AV, et al. Recognizing symptom burden in advanced prostate cancer: A global patient and caregiver survey. Clin Genitourin Cancer. 2018;16(2):e411-e9.

8. McKay R, Haider B, Duh MS, Valderrama A, Nakabayashi M, Fiorillo $\mathrm{M}$, et al. Impact of symptomatic skeletal events on health-care resource utilization and quality of life among patients with castration-resistant prostate cancer and bone metastases. Prostate Cancer Prostatic Dis. 2017;20(3):276-82.

9. Alemayehu B, Buysman E, Parry D, Becker L, Nathan F. Economic burden and healthcare utilization associated with castration-resistant prostate cancer in a commercial and Medicare Advantage US patient population. J Med Econ. 2010;13(2):351-61.

10. Albers P, Heicappell R, Schwaibold H, Wolff J. German Association of Urological Oncology SotGCS. Erythropoietin in urologic oncology. Eur Urol. 2001;39(1):1-8.
11. Shamdas GJ, Ahmann FR, Matzner MB, Ritchie JM. Leukoerythroblastic anemia in metastatic prostate cancer. Clinical and prognostic significance in patients with hormone-refractory disease. Cancer. 1993;71(11):3594-600.

12. Kanuri G, Sawhney R, Varghese J, Britto M, Shet A. Iron deficiency anemia coexists with cancer related anemia and adversely impacts quality of life. PLoS ONE. 2016;11(9):e163817.

13. Integraal Kankercentrum Nederland. Richtlijn wervelmetastasen. Versie 1.0. 2015. www.oncoline.nl/wervelmetastasen. Geraadpleegd op: 15 jul 2019.

14. Bollen L, Linden YM van der, Pondaag W, Fiocco M, Pattynama BP, Marijnen CA, et al. Prognostic factors associated with survival in patients with symptomatic spinal bone metastases: A retrospective cohort study of 1,043 patients. Neuro Oncol. 2014;16(7):991-8.

15. Wallander M, Axelsson KF, Lundh D, Lorentzon M. Patients with prostate cancer and androgen deprivation therapy have increased risk of fractures-a study from the fractures and fall injuries in the elderly cohort (FRAILCO). Osteoporos Int. 2019;30(1):115-25.

16. Jefferies ER, Bahl A, Hounsome L, Eylert MF, Verne J, Persad RA, et al. Admissions to hospital due to fracture in England in patients with prostate cancer treated with androgen-deprivation therapy-Do we have to worry about the hormones? BJU Int. 2016;118(3):416-22.

17. Integraal Kankercentrum Nederland. Richtlijn lymfoedeem. Versie 1.0. 2014. www.oncoline.nl/lymfoedeem. Geraadpleegd op: $15 \mathrm{jul}$ 2019.

18. Hung AK. Severe hypocalcaemia as a cause of seemingly idiopathic bilateral lower limb oedema. BMJ Case Rep. 2014; https://doi.org/ 10.1136/bcr-2013-201387.

19. Zhu J, Liao R, Su C, Liang D, Wu J, Qiu K, et al. Toxicity profile characteristics of novel androgen-deprivation therapy agents in patients with prostate cancer: A meta-analysis. Expert Rev Anticancer Ther. 2018;18(2):193-8.

20. Won AC, Gurney H, Marx G, De Souza P, Patel MI. Primary treatment of the prostate improves local palliation in men who ultimately develop castrate-resistant prostate cancer. BJU Int. 2013;112(4):E250-E5.

21. Rom M, Waldert M, Schatzl G, Swietek N, Shariat SF, Klatte T. Bladder outlet obstruction (BOO) in men with castration-resistant prostate cancer. BJU Int. 2014;114(1):62-6.

22. Benoist GE, Oort IM van, Burger DM, Koch BCP, Mehra N, Erp NP van. The combination of enzalutamide and opioids: A painful pitfall? Eur Urol. 2019;75(2):351-2.

23. Spencer BA, Insel BJ, Hershman DL, Benson MC, Neugut AI. Racial disparities in the use of palliative therapy for ureteral obstruction among elderly patients with advanced prostate cancer. Support Care Cancer. 2013;21(5):1303-11.

24. Haddad FS. Metastases to the ureter. Review of the world literature, and three new case reports. J Med Liban. 1999;47(4):265-71.

25. Mason MD, Parulekar WR, Sydes MR, Brundage M, Kirkbride P, Gospodarowicz M, et al. Final report of the intergroup randomized study of combined androgen-deprivation therapy plus radiotherapy versus androgen-deprivation therapy alone in locally advanced prostate cancer. J Clin Oncol. 2015;33(19):2143-50.

26. Warde P, Mason M, Ding K, Kirkbride P, Brundage M, Cowan R, et al. Combined androgen deprivation therapy and radiation therapy for locally advanced prostate cancer: A randomised, phase 3 trial. Lancet. 2011;378(9809):2104-11.

27. Wilding S, Downing A, Wright P, Selby P, Watson E, Wagland R, et al. Cancer-related symptoms, mental well-being, and psychological distress in men diagnosed with prostate cancer treated with androgen deprivation therapy. Qual Life Res. 2019; https://doi.org/ 10.1007/s11136-019-02212-x. 
28. Roviello G, Generali D. Is the fatigue an adverse event of the second generation of hormonal therapy? Data from a literature-based metaanalysis. Med Oncol. 2018;35(3):29.

29. Snijder M, Andel JL van, Andel G van. Het klinisch beloop bij patiënten met een primair gemetastaseerd prostaatcarcinoom. 2010. Voordracht NVU.

30. Boevé LMS, Hulshof MCCM, Vis AN, Zwinderman AH, Twisk JWR, Witjes WPJ, et al. Effect on survival of androgen deprivation therapy alone compared to androgen deprivation therapy combined with concurrent radiation therapy to the prostate in patients with primary bone metastatic prostate cancer in a prospective randomised clinical trial: Data from the HORRAD trial. Eur Urol. 2019;75(3):410-8.

31. Boevé LMS, Hulshof MCCM, Vis AN, de Vries P, van Moorselaar RJA, Witjes WPJ, Verhagen PCMS, van Andel G. Lokale behandeling bij het primair gemetastaseerd prostaatcarcinoom. Tijdschr Urol. 2019. In druk.

32. Nishimura K, Nonomura N, Yasunaga Y, Takaha N, Inoue H, Sugao $\mathrm{H}$, et al. Low doses of oral dexamethasone for hormone-refractory prostate carcinoma. Cancer. 2000;89(12):2570-6.

33. Clarke MJ, Molina CA, Fourney DR, Fisher CG, Gokaslan ZL, Schmidt MH, et al. Systematic review of the outcomes of surgical treatment of prostate metastases to the spine. Global Spine J. 2017;7(5):460-8.

34. Baumfalk AE, Verlaan JJ, Kasperts N, Amelink GJ, Minnema MC, Snijders TJ. Spinal metastases: Early recognition and a multidisciplinary approach. Ned Tijdschr Geneeskd. 2019;163:D3961.

35. European Association of Urology. Guideliness on prostate cancer. 2018.

36. Macherey S, Monsef I, Jahn F, Jordan K, Yuen KK, Heidenreich A, et al. Bisphosphonates for advanced prostate cancer. Cochrane Database Syst Rev. 2017;12:CD6250.

37. Briot K, Paccou J, Beuzeboc P, Bonneterre J, Bouvard B, Confavreux $\mathrm{CB}$, et al. French recommendations for osteoporosis prevention and treatment in patients with prostate cancer treated by androgen deprivation. Joint Bone Spine. 2019;86(1):21-8.

38. Broder MS, Gutierrez B, Cherepanov D, Linhares Y. Burden of skeletal-related events in prostate cancer: Unmet need in pain improvement. Support Care Cancer. 2015;23(1):237-47.

39. Pelletier J, Cyr SJ, Julien AS, Fradet Y, Lacombe L, Toren P. Contemporary outcomes of palliative transurethral resection of the prostate in patients with locally advanced prostate cancer. Urol Oncol. 2018;36(8):363.e7-363.e11.

40. Mougin J, Souday V, Martin F, Azzouzi AR, Bigot P. Evaluation of hyperbaric oxygen therapy in the treatment of radiation-induced hemorrhagic cystitis. Urology. 2016;94:42-6.

41. Tanaka T, Minami A, Uchida J, Nakatani T. Potential of hyperbaric oxygen in urological diseases. Int J Urol. 2019; https://doi.org/10. 1111/iju.14015.

42. Pereira K, Halpern JA, McClure TD, Lewis NA, Kably I, Bhatia $\mathrm{S}$, et al. Role of prostate artery embolization in the management of refractory haematuria of prostatic origin. BJU Int. 2016;118(3):359-65.

43. Heidenreich A, Porres D, Pfister D. The role of palliative surgery in castration-resistant prostate cancer. Oncol Res Treat. 2015;38(12):670-7.

44. Integraal Kankercentrum Nederland. Richtlijn palliatieve pijn. Versie 2.1. 2016. www.pallialine.nl/pijn. Geraadpleegd op: 15 jul 2019.
45. Bootsma JEM, Cornelissen P, Marum RJ van. Medicinal treatment of pain in the elderly: 10 tips from clinical pharmacology. Ned Tijdschr Geneeskd. 2019;163:D2984.

46. McQuay HJ, Collins SL, Carroll D, Moore RA. Radiotherapy for the palliation of painful bone metastases. Cochrane Database Syst Rev. 2000;2:CD1793.

47. Dy SM, Asch SM, Naeim A, Sanati H, Walling A, Lorenz KA. Evidence-based standards for cancer pain management. J Clin Oncol. 2008;26(23):3879-85.

48. Linden YM van der, Lok JJ, Steenland E, Martijn H, Houwelingen $\mathrm{H}$ van, Marijnen CA, et al. Single fraction radiotherapy is efficacious: a further analysis of the Dutch Bone Metastasis Study controlling for the influence of retreatment. Int J Radiat Oncol Biol Phys. 2004;59(2):528-37.

49. Nielsen OS, Bentzen SM, Sandberg E, Gadeberg CC, Timothy AR. Randomized trial of single dose versus fractionated palliative radiotherapy of bone metastases. Radiother Oncol. 1998;47(3):233-40.

50. Paes FM, Serafini AN. Systemic metabolic radiopharmaceutical therapy in the treatment of metastatic bone pain. Semin Nucl Med. 2010;40(2):89-104.

51. Dennett AM, Peiris CL, Shields N, Prendergast LA, Taylor NF. Moderate-intensity exercise reduces fatigue and improves mobility in cancer survivors: A systematic review and meta-regression. J Physiother. 2016;62(2):68-82.

52. Taaffe DR, Newton RU, Spry N, Joseph D, Chambers SK, Gardiner RA, et al. Effects of different exercise modalities on fatigue in prostate cancer patients undergoing androgen deprivation therapy: A year-long randomised controlled trial. Eur Urol. 2017;72(2):293-9.

53. Downing A, Wright P, Hounsome L, Selby P, Wilding S, Watson E, et al. Quality of life in men living with advanced and localised prostate cancer in the UK: A population-based study. Lancet Oncol. 2019;20(3):436-47.

54. Body JJ, Moos R von, Rider A, Hallworth P, Bhowmik D, Gatta F, et al. A real-world study assessing the use of bone-targeted agents and their impact on bone metastases in patients with prostate cancer treated in clinical practice in Europe. $\mathrm{J}$ Bone Oncol. 2019;14:100212.

55. Cella D, Traina S, Li T, Johnson K, Ho KF, Molina A, et al. Relationship between patient-reported outcomes and clinical outcomes in metastatic castration-resistant prostate cancer: Post hoc analysis of COU-AA-301 and COU-AA-302. Ann Oncol. 2018;29(2):392-7.

56. Basch E, Deal AM, Dueck AC, Scher HI, Kris MG, Hudis C, et al. Overall survival results of a trial assessing patient-reported outcomes for symptom monitoring during routine cancer treatment. JAMA. 2017;318(2):197-8.

drs. Ronald W. ter Haar aios urologie

drs. Liselotte M.S. Boevé uroloog

drs. Jasper J. Hillenius student-onderzoeker geneeskunde

dr. George van Andel uroloog 